Original Article

\title{
IN VITRO EFFICACY TESTING OF NEEM (AZADIRACHTA INDICA) EXTRACT AGAINST AEROBIC AND ANAEROBIC BACTERIA
}

\author{
AKSHAYA S. R. ${ }^{1}$, G. BHUVANESHWARI ${ }^{2}$, J. R. LILLY GRACE ${ }^{3}$, ROSY VENNILA4
}

${ }^{1}$ MBBS Student, Saveetha Medical College and Hospital, ${ }^{2}$ Microbiology Department Professor, Saveetha Medical College and Hospital, ${ }^{3}$ MSc Medical Microbiology, Saveetha Medical College and Hospital, ${ }^{4} \mathrm{HOD}$ Microbiolgy Department, Saveetha Medical College and Hospital

Email: akshayarajenthren@gmail.com

Received: 10 Jul 2020, Revised and Accepted: 08 Sep 2020

ABSTRACT

Objective: To experiment the antimicrobial susceptibility of crude extract from neem (Azadirachta indica) leaves against Staphylococcus aureus, Escherichia coli and Clostridium perfringens.

Methods: Through the water extraction method, the aqueous crude extract of neem leaves were obtained. Separate colonies of Staphylococcus aureus, Escherichia coli and Clostridium perfringens were isolated and identified on different agars. Agar cup diffusion method was done to test the antimicrobial susceptibility of the neem leaves crude extract against those bacteria on Mueller-Hinton agar. Susceptibility was determined based on the zone of inhibition formed on the agar of each bacterium culture.

Result: Neem was effective against Staphylococcus aureus and Clostridium perfringens. It was not effective against Escherichia coli.

Conclusion: Neem extract has some promisable antimicrobial effects against Staphylococcus aureus and Clostridium perfringens causative bacterial infections.

Keywords: Antimicrobial susceptibility testing, Staphylococcus aureus, Escherichia coli, Clostridium perfringens, Crude extract of neem (Azadirachta indica) leaves, Agar cup diffusion method, Zone of inhibition

(C) 2020 The Authors. Published by Innovare Academic Sciences Pvt Ltd. This is an open access article under the CC BY license (http://creativecommons.org/licenses/by/4.0/) DOI: http://dx.doi.org/10.22159/ijcpr.2020v12i6.40307. Journal homepage: https://innovareacademics.in/journals/index.php/ijcpr

\section{INTRODUCTION}

Infections remain the main cause of morbidity and mortality. Bacterial infections and antibiotic bacterial resistance are emerging problem. This study is performed on selected bacterial organisms like Staphylococcus aureus, Escherichia coli and Clostridium perfringens. Staphylococcus, anaerobic gram $(+)$ cocci is a primary parasite of human beings, colonizing in skin and mucous membranes. Staphylococcus infections are the most common bacterial infections and ranges from trivial to fatal and are among the more resistant non-sporing bacteria. Nosocomial infection of Staphylococcus like postoperative wound infections and other crossreactions are very frequent and it is caused by strains resistant to various antibiotics eg-MRSA. Escherichia coli, an aerobic and facultative anaerobic gram $(-)$ bacilli is a parasite, living only in human or animal intestine. They account largely for naturally acquired urinary tract infections. About 5-7 \% of pregnant women are reported to have asymptomatic UTI, which when untreated, may cause symptomatic infections like pyelonephritis and hypertension. Clostridium perfringens, an anaerobic gram $(+)$ spore-forming bacilli is a normal inhabitant of the human intestine. They are the most important in causing various human infections like gas gangrene, necrotising enteritis, biliary tract infections, and food poisoning. Gas gangrene, also called as clostridial myonecrosis is a disease of war and are mostly caused by species of Clostridium in association with facultative anaerobes like Escherichia coli and aerobes like Staphylococcus.

The advantages of traditional medicines include reduced side effects and allergies. So in this respect, neem leaves are found to be more effective and has promising antimicrobial activity. Each part has different medicinal properties like antibacterial, antiviral, antifungal, antimalarial, anticarcinogenic, antiseptic, antipyretic, antiinflammatory, anti-oxidant [1]

In India, neem leaves are used to treat chickenpox [2] andin Thailand; they are given as a tonic for fever [3]. The aqueous crude neem leave extract has significant hypoglycaemic [4] and hypolipidemic properties. The prevalence of increasing infections of aerobic and anaerobic bacteria and their increasing resistance towards antibiotics have urged for more alternative medicines. Hence the aim of this research study is to evaluate the in-vitro efficacy of neem extract against aerobic and anaerobic bacteria.

\section{MATERIALS AND METHODS}

\section{Crude extraction procedure}

The neem (Azadirachta indica) leaves were cleaned and dried using hot air oven at 55 degree $\mathrm{C}$ for $6 \mathrm{~h}$ and then powdered by grinding machine. The dried neem leaves powder were boiled with distilled water for $6 \mathrm{~h}$ and then filtered. The filtrate was then evaporated in a vacuum evaporator to yield the aqueous crude extract of neem leaves [1].

\section{Isolation and identification of the organisms}

\section{a) Staphylococcus aureus}

Isolates were cultured on nutrient agar after incubation for 24-48 $\mathrm{h}$ at $37{ }^{\circ} \mathrm{C}$ [5]. The colonies formed were large $(2-4 \mathrm{~mm})$, convex, opaque white and easily emulsifiable. They were then subcultured on blood agar with sheep blood; most strains were hemolytic. The colonies were identified with gram staining (gram+ve cocci, irregular and grape-like cluster arrangement), hemolysis (beta hemolysis), coagulase test (+ve).

\section{b) Escherichia coli}

Isolation was done on blood agar and MacConkey agar. They were incubated for $24-48 \mathrm{~h}$ at $37^{\circ} \mathrm{C}$ [6]. The colonies were then identified using some standard biochemical tests like indole (+ve), methyl red (+ve), citrate (-ve), Vogues-Proskauer (-ve).

\section{c) Clostridium Perfringens}

For isolation, Robertson's cooked meat broth (enrichment) was inoculated with the Clostridium perfringens and incubated for 4-6 h 
at 45 degree C. It was then subcultered on blood agar (sheep blood) to yield pure growth of Clostridium perfringens. The colonies were identified with nagler's reaction (for lecithinase activity) [7], litmus milk fermentation (litmus-blue to red), and target hemolysis (theta and alpha-toxin).

\section{Antimicrobial susceptibility testing}

\section{a) Agar cup diffusion method}

Also called as Kirby-Bauer method is an antibiotic susceptibility testing method. It is used to find the susceptibility of a bacterium to an antibiotic. Mueller-Hinton Agar is usually used as it is the best for antimicrobial susceptibility testing and has good reproducibility and gives satisfactory growth of wide range of pathogens [8].

\section{Principle}

The antibiotic-impregnated disk, when placed over an already inoculated agar medium with the test bacterium, would pick up moisture and the antibiotic would diffuse radially outward on the medium. It produces a gradient of high concentration of antibiotics at the edges of the disk and slowly the concentration decreases as it diffuses radially outward. Thus creating a zone of inhibition around the disk, where the bacterium could not grow if the antibiotic is effective against the test bacterium [8].

\section{Procedure}

\section{Preparation of MHA medium}

MHA is prepared from dehydrated medium using distilled water or deionised water. It's heated to dissolve completely, followed by autoclaving at 121 degree $\mathrm{C}$ for $15 \mathrm{~min}$. Then $\mathrm{pH}$ was checked after each sterilization, which should range between 7.2-7.4. The agar was cooled at 40-50 degree $\mathrm{C}$ and poured on a sterile petridish in a uniform depth of $4 \mathrm{~mm}$. Prior to use the petridishes were dried at
30-37 degree $C$ at an incubator till the excess surface moisture was evaporated. Likewise, three petridishes were made, one for each bacterium [8].

\section{Inoculation of the bacteria on the MHA medium}

Ideal colonies of each bacterium from their respective subcultures were swooped with a sterilised inoculating loop and streaked over on each of the three MHA medium, by rotating the plate 60 degree and repeating the procedure to ensure uniform inoculation. The area where the streaking was started was marked [8]

\section{Placement of the antimicrobial disks}

Using sterile forceps, antimicrobial disks of neem extract were placed over the inoculated medium and immediately pressed gently to ensure complete contact of the disk and the agar medium. Then they were incubated at 37 degree $\mathrm{C}$ for $24 \mathrm{~h}$ [8].

\section{Zone of inhibition}

After leaving it undisturbed for 16-18 h, they were taken to observe for the zone of inhibition [8].

\section{RESULT AND DISCUSSION}

As per the observations seen in the culture mediums, neem extract shows antimicrobial activity with zone of inhibition of $22 \mathrm{~mm}$ against gram-positive bacteria like Staphylococcus aureus and zone of inhibition of $12 \mathrm{~mm}$ against anaerobic bacteria like Clostridium perfringens. It is not effective against gram-negative bacteria like Escherichia coli with no zone of inhibition. Similar results were obtained in many researchers where the antimicrobial activity of aqueous crude extract of neem leaves against Staphylococcus aureus and Escherichia coli have been demonstrated [9]. Previous researches have shown similar results of antimicrobial susceptibility of neem against Clostridium perfringens with mild zone of inhibition.

\section{Antimicrobial activity of crude neem extract by agar cup diffusion method.}

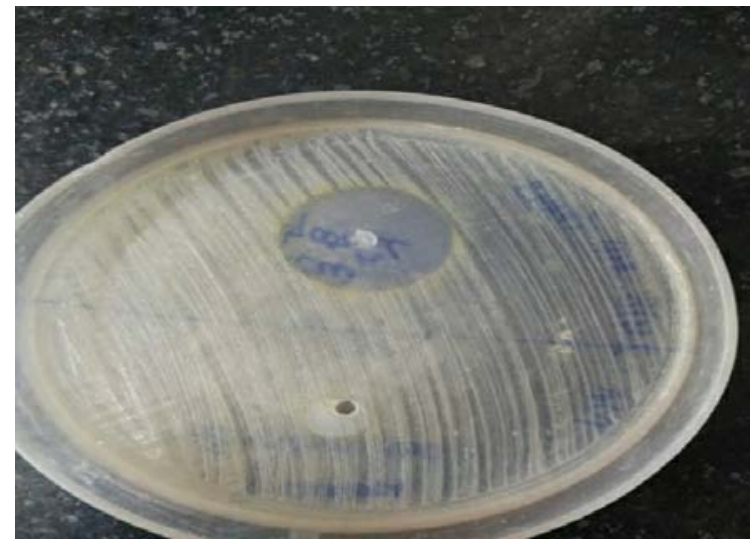

Fig. 1A): Staphylococcus aureus

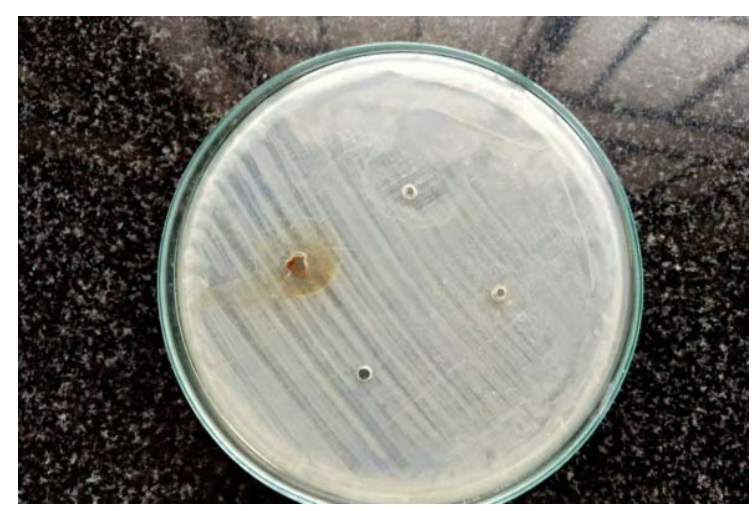

Fig. 2B): Escherichia coli 


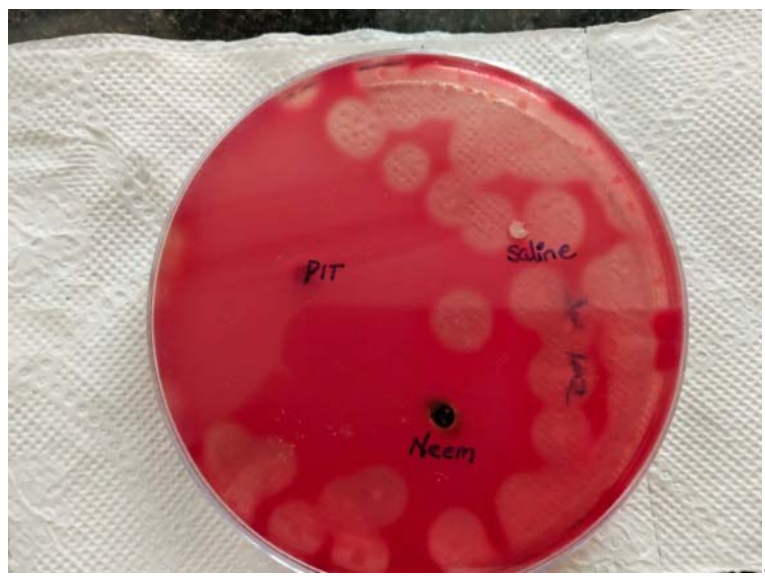

Fig. 3C): Clostridium perfringens

\section{CONCLUSION}

Azadirachta indica (neem) leave extract has important medicinal properties like anti-inflammatory, antibacterial, antiviral, antifungal [10] and much more. This study concludes that the crude extract of Azadirachta indica (neem) leaves have sensitivity against grampositive bacteria like Staphylococcus aureus and anaerobes like Clostridium perfringens. Thus it can be used as an alternative in therapeutic forms to many gram-positive and anaerobic bacterial infections. Future studies on Azadirachta indica should be done using crystallography, as the neem plant shows promisable antimicrobial activity.

\section{ACKNOWLEDGEMENT}

Highly thankful to the mentors, the HOD of the microbiology department, the Dean and the management of The Saveetha Medical College and Hospital, Chennai, for the opportunity and the laboratory facility.

\section{FUNDING}

Nil

\section{AUTHORS CONTRIBUTIONS}

All the authors have contributed equally.

\section{CONFLICT OF INTERESTS}

Declared none

\section{REFERENCES}

1. Voravuth Somsak, Sukanya Chachiyo, Ubonwan Jaihan, Somrudee Nakinchat. Protective effect of aqueous crude extract of neem (Azadirachta indica) leaves on Plasmodium berghei- induced renal damages in mice. J Tropic Med 2015:1-5. DOI:10.1155/2015/961205

2. M Asif. Antimicrobial potential of Azadirachta indica against pathogenic bacteria and fungi. J Pharmacol Phytochem 2012;1:78-83.

3. $\mathrm{MB}$ Mohashine, $\mathrm{M}$ Nishimura, $\mathrm{S}$ Matsumura, $\mathrm{T}$ Shimono. Antimicrobial effect of the crude Azadirachtaindica neem bark extract on Streptococcus sobrinus. Pediatr Dent J 2009;7:61-4.

4. L Sunarwidhi, S Sudarsono, AE Nugroho. Hypoglycemic effect of combination of Azadirachta indica A. Juss and Gynuraprocumbens (Lour) merr ethanolic standardized by rutin and quercetin in alloxan-induced hyperglycaemic rats. Adv Pharm Bull 2014;4:613-8.

5. Acco M, Ferreira FS, Henriques JAP, Tondo EC. Identification of multiple stains of Staphylococcus aureus colonizing nasal mucosa of food handlers. Food Microbiol 2003;20:483-93.

6. Sudheendra Ramesh Kulkarni, Basavaraj V Peerapur, Kumar Sai Sailesh. Isolation and antibiotic susceptibility pattern of Escherichia coli from urinary tract infections in a tertiary care hospital of North Eastern Karnataka. J Nat Sci Biol Med 2017;8:176-80.

7. Fahim A Shaltout, Islam M Osman, Enas A Kamel, Amira K AbdAlla. Isolation of Clostridium perfringens from meat samples obtained from a university student's hostel. EC Nutrition 2017;9:142-50.

8. Tendencia, Eleonor A. Disk diffusion method. SEAFDEC, Aquaculture Department Japan, Chapter 2; 2004. p. 14-29.

9. Maragathavalli S, Brindha S, Kaviyarasi NSB, Annadurai B, Gangwar SK. Antimicrobial activity in leaf extract of neem (Azadirachta indica). IJSN 2012;3:110-3.

10. Ranjit R Raut, Aji R Sawant, Bhagyashree BJ Amge. Antimicrobial activity of Azadirachta indica (Neem) against pathogenic microorganisms. J AIR 2014;3:327-9. 